\title{
ANALISIS DAN PERBANDINGAN SEGITIGA KERJA: TURBIN SUDU SETENGAH LINGKARAN, SUDU SEGITIGA DAN SUDU SIRIP UNTUK MENGHASILKAN RPM YANG TERTINGGI
}

\author{
Gregory Rama Darantiah Ruing ${ }^{1}$, Antonius lbi Weking ${ }^{2}$, Lie Jasa ${ }^{3}$ \\ ${ }^{1,2,3}$ Program Studi Teknik Elektro, Fakultas Teknik, Universitas Udayana \\ Email : jerryrama@gmail.com ${ }^{1}$, tony@unud.ac.id ${ }^{2}$, liejasa@unud.ac.id ${ }^{3}$
}

\begin{abstract}
Abstrak
Saat ini pembangkit listrik memiliki ketergantungan yang tinggi terhadap sumber energi seperti solar, gas alam dan batubara, sedangkan sumber energi tersebut keberadaannya di alam sudah semakin langka, situasi ini mendorong dikembangkannya energi terbarukan salah satunya adalah pada pembangkit listrik tenaga mikro hidro. Penelitian ini bertujuan untuk mengetahui pengaruh dari luas segitiga kerja terhadap rpm tertinggi yang dihasilkan. jatuhnya air pada kincir diatur dari sudut posisi nozzle $0^{\circ}, 15^{\circ}, 30^{\circ}, 45^{\circ}, 60^{\circ}, 75^{\circ}$ dan dari sudut nozzle $0^{\circ}$, $5^{\circ}, 10^{\circ}, 15^{\circ}, 20^{\circ}, 25^{\circ}, 30^{\circ}, 35^{\circ}$ dan $40^{\circ}$ pada turbin sudu setengah lingkaran, turbin sudu segitiga, dan turbin sudu sirip. Sudu turbin setengah lingkaran, luas segitiga kerja menghasilkan rpm yang semakin besar pada posisi sudut nozzle $0^{\circ}$ dan sudut nozzle $25^{\circ}$ dengan luasan segitiga kerja $360,36 \mathrm{~cm}^{2}$, dimana posisi tersebut menghasilkan $216 \mathrm{rpm}$ pada putaran kincir dan 1626 rpm pada putaran generator. Pada saat sudut posisi nozzle $15^{\circ}$ dan sudut nozzle $20^{\circ}$ dengan luasan segitiga kerja 264,27 cm ${ }^{2}$, menghasilkan $221 \mathrm{rpm}$ pada putaran kincir dan 1711 rpm pada putaran generator. sedangkan pada saat sudut posisi nozzle $30^{\circ}$ dan sudut nozzle $10^{\circ}$ luas segitiga kerjanya 134,37 $\mathrm{cm}^{2}$ dan menghasilkan $173 \mathrm{rpm}$ pada putaran kincir dan 1307 rpm pada putaran generator. pada turbin sudu segitiga dan sudu sirip, luas segitiga kerja tidak berpengaruh terhadap rpm yang dihasilkan.
\end{abstract}

Kata kunci :PLTMH, Sudut Nozzle, Posisi Nozzle, Segitiga Kerja

\section{Abstract}

At present the power plant has a high dependence on energy sources such as diesel, natural gas and coal, while its energy source in nature is increasingly scarce, this situation encourages the development of renewable energy, one of which is in micro hydro power plants. This study aims to determine the effect of the width of the work triangle on the highest rpm produced. the fall of water on the pinwheel is set from the position angle of the nozzle 00, 150, $300,450,600,750$ and from the angle of the nozzle 00, 50, 100, 150, 200, 250, 300, 350 and 400 on the semicircular blade turbine, triangle blade turbine, and fin blade turbines. Semicircular turbine blade, working triangle area produces greater rpm at position of angle nozzle 00 and angle of nozzle 250 with area of work triangle $360,36 \mathrm{~cm} 2$, where the position produces $216 \mathrm{rpm}$ at windmill rotation and $1626 \mathrm{rpm}$ at generator rotation. When the nozzle position angle 150 and the nozzle angle 200 with the working triangle area $264.27 \mathrm{~cm} 2$, produce $221 \mathrm{rpm}$ at the pinwheel rotation and $1711 \mathrm{rpm}$ at the generator rotation. while at the nozzle position angle of 300 and the angle of the nozzle 100 the area of the triangle works $134.37 \mathrm{~cm} 2$ and produces $173 \mathrm{rpm}$ at the spinning wheel and $1307 \mathrm{rpm}$ at the generator rotation. on the triangle blade turbine and fin blade, the working triangle area does not affect the rpm produced.

Keywords: PLTMH, Nozzle Position Angle, Angle of the Nozzle, Working Triangle 


\section{PENDAHULUAN}

Krisis listrik yang terjadi di Indonesia disebabkan oleh ketidak sesuaian antara kebutuhan masyarakat yang semakin meningkat dari waktu ke waktu dan kemampuan pemerintah menyediakan listrik. Sampai saat ini, sumber energi pembangkit listrik di Indonesia sebagian besar tergantung pada solar, gas alam, dan batubara yang hampir di atas $75 \%$. Ketiga jenis bahan bakar ini membutuhkan transportasi agar dapat sampai ke lokasi pembangkit listrik. Jika transportasi pengangkut bahan bakar ini terganggu karena cuaca buruk atau gelombang laut besar, pembangkit listrik akan terganggu. Sebagaimana yang kita rasakan, fenomena yang banyak terjadi akhir - akhir ini adalah pemadaman listrik secara bergilir baik di kota - kota besar maupun di daerah. [1]

Melihat kondisi ini, sejak tahun 2000 telah digalakkan program hemat energi untuk mengantisipasi kekurangan daya tersebut, yaitu dengan mengurangi pemakaian sumber energi primer dari BBM dan beralih ke sumber energi thermal, seperti : batu bara, gas dan panas bumi, matahari (solar energi) dan hydro (air) serta pemanfaatan energi alternatif seperti energi surya, angin, dan energi samudra. [2]

Salah satu pembangkit energi listrik yang ada saat ini adalah PLTMH, dimana PLTMH adalah pembangkit listrik tenaga mikro hidro yang artinya pembangkit listrik ini menggunakan energi dari tenaga air untuk menghasilkan energi listrik. Pembangkit listrik mikro hidro adalah pembangkit listrik tenaga air yang tidak memerlukan bendungan besar seperti pada pembangkit listrik tenaga air pada umumnya. Air yang jatuh dari nozzle sampai menyentuh permukaan sudu dimana nozzle bisa dirubah-rubah sudutnya sehingga membentuk suatu segitiga. Yang dimaksud segitiga kerja adalah air yang mengenai sudu menyebabkan sudu berputar, bila sudutnya terlalu besar air tidak mengenai permukaan sudu sehingga turbin tidak berputar, maka dalam hal ini dinyatakan sudah melewati segitiga kerja. Pada penelitian ini akan dibahas mengenai pengaruh segitiga kerja terhadap rpm tertinggi yang dihasilkan, yang ditentukan oleh sudut posisi nozzle dan sudut nozzle.

\section{KAJIAN PUSTAKA}

\subsection{Mikro Hidroo}

Pembangkit Listrik Tenaga Mikro Hidro (PLTMH) adalah pembangkit listrik berskala kecil (kurang dari 200 kW) yang memanfaatkan aliran air sebagai sumber energi terbarukan dan layak disebut clean energy karena ramah lingkungan.

Secara ekonomis, biaya operasi investasinya cukup bersaing dengan pembangkit listrik lainnya. Secara sosial, PLTMH mudah diterima oleh masyarakat luas. PLTMH biasanya dibuat dalam skala desa di daerah-daerah terpencil yang belum mendapatkan listrik dari PLN. Tenaga air yang digunakan dapat berupa aliran air pada sistem irigasi, sungai yang di bending atau air terjun.[3]

Pemilihan jenis turbin berdasarkan head diperlihatkan pada Gambar 1,

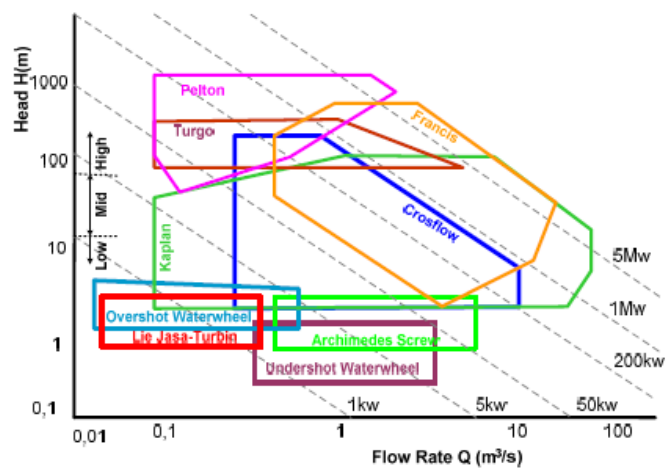

Gambar 1. Grafik pemilihan jenis turbin

Sebuah pembangkit listrik mikro hidro lokasinya cenderung tersebar pada daerah pengunungan yang memiliki beda ketinggian. Air yang mengalir diantara celahcelah bukit mulai dari hulu debitnya kecil, semakin kebawah makin besar setelah melalui penggabungan dari beberapa celah lereng bukit. Konsep dari aliran air ini mengalir sepanjang waktu, tidak ada genangan yang menampung air dalam volume yang besar. Konsep waduk ditempat seperti ini tidak memungkinkan, bila ditemukan air terjun, maka dilokasi itu memungkinkan bisa dimanfaatkan sebagai pembangkit energi listrik.

\subsection{Jenis Kincir}

Kincir air digunakan untuk merubah energi air yang mengalir menjadi energi kinetis dalam bentuk energi putaran, semakin besar air yang memutar kincir ini semakin besar momen energi putar yang 
didapat. Jenis-jenis kincir air yang diukur adalah:

1. Sudu Turbin Setengah Lingkaran Turbin setengah lingkaran terdiri dari dua bagian utama yaitu nozzle dan runner. Nozzle merupakan bagian yang diam sedangkan runner merupakan bagian yang bergerak. Runner terbuat dari dua buah piringan sejajar yang digabungkan oleh sederetan sudu melengkung di bagian tepi. Bentuk nozzle dalam penelitian ini adalah bulat untuk mengarahkan pancaran air kedalam sudu. [4]

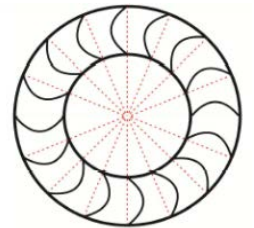

Gambar 2. Sudu Turbin Setengah Lingkaran

\section{Sudu Turbin Segitiga}

Model kincir dibuat dalam posisi berdiri, dan sudu yang ditempatkan ditepi lingkaran luar antara dua piringan roda. Air akan tertahan pada celah ruang diantara piringan dengan alas sudu. Air akan tertahan pada ruang ini karena adanya pengaruh gaya gravitasi terhadap masa air yang menyebabkan roda turbin berputar pada porosnya. Dalam penelitian ini jumlah sudu dirancang sebanyak 8 buah berbentuk segitiga yang melekat di tepi roda.Dalam menentukan jumlah sudu turbin, tetap dipertimbangkan dari jarijari turbin bagian luar karena jarak antara sudu dihitung berdasarkan keliling lingkaran luar dibagi dengan jumlah sudu (N). [4]

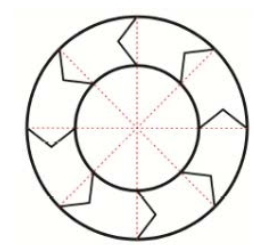

Gambar 3. Sudu Turbin Segitiga

3. Sudu Turbin Sirip

Turbin sudu sirip adalah turbin air yang memiliki sudu-sudu berbentuk sirip yang dipasang pada bagian tepi dari pinggiran roda. Air yang mengalir melalui pipa pesat (penstock) akan mengisi sudu-sudu yang menyebabkan turbin berputar. [4]

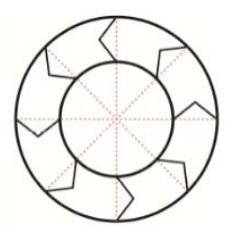

Gambar 4. Sudu Turbin Sirip

\subsection{Desain Posisi dan Arah Sudut Nozzle}

\subsubsection{Posisi Nozzle}

Sudut posisi nozzle adalah sudut yang terbentuk antara lengan nozzle dan garis vertikal. Besarnya sudut akan berubah sesuai kedudukan posisi lengan nozzle, yang tentunya besar dari sudut posisi nozzle lebih kecil dari $90^{\circ}$ dan arahnya selalu tertuju pada sudu. [4]

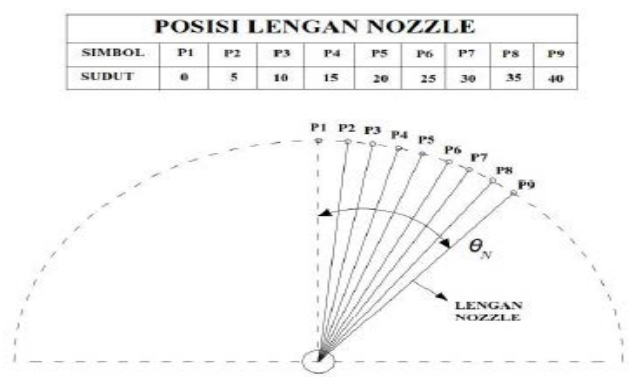

Gambar 5. Posisi lengan nozzle

\subsubsection{Arah Sudut Nozzle}

Panjang dari lengan nozzle harus lebih besar dari jari-jari roda sehingga nozzle selalu berada di luar dari lingkungan roda. Sudut $\mathrm{aN}$ adalah sudut yang terbentuk antara lengan nozzle dengan nozzle. Besarnya aN dibuat antara $0^{\circ}, 5^{\circ}, 10^{\circ}, 15^{\circ}$, $20^{\circ}, 25^{\circ}$, dan $30^{\circ}$ berdasarkan kedudukan dari lengan nozzle. Range sudut $\alpha \mathrm{N}<90^{\circ}$, dengan arah ditunjukkan pada sudu. [5]

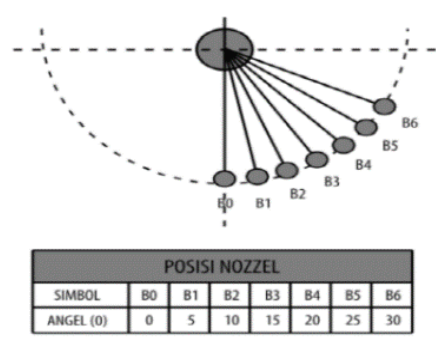

Gambar 6. Arah Sudut Nozzle 


\section{METODE PENELITIAN}

\subsection{Alur Penelitian}

Secara sistematik alur penelitian dapat dilihat pada gambar dibawah ini:

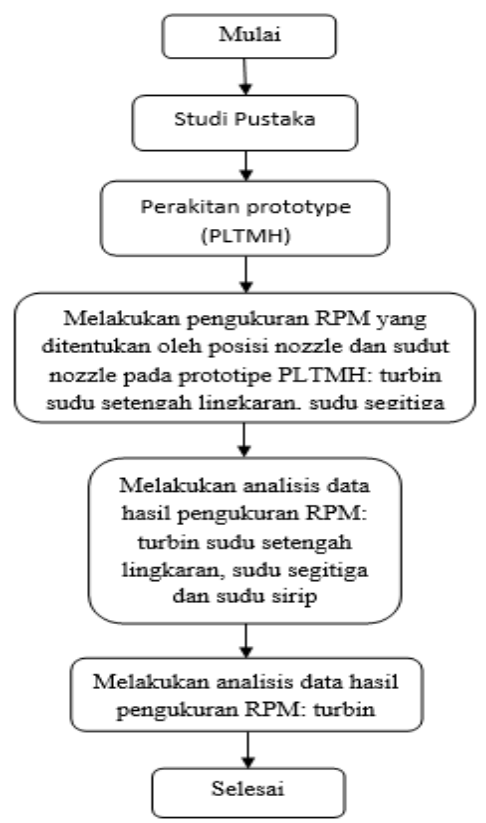

Gambar 7. Alur Penelitian

Metodelogi dalam penelitian ini dilakukan dalam beberapa tahapan sebagai berikut :

1. Melakukan studi literatur.

2. Merakit kincir dan pompa dengan kerangkanya sehingga menjadi satu bagian.

3. Melakukan pengukuran kecepatan rpm menggunakan alat ukur tachometer dengan mengatur titik jatuh air di sudut $\mathrm{P} 1=0^{\circ}, \mathrm{P} 2=15^{\circ}, \mathrm{P} 3=30^{\circ}, \mathrm{P} 4=45^{\circ}, \mathrm{P} 5=60^{\circ}$, dan $P 6=75^{\circ}$ terhadap titik utama kincir dan mengganti arah sudut nozzle pada setiap posisi nozzle berturut-turut dari $0^{0}$, $5^{\circ}, 10^{\circ}, 15^{\circ}, 20^{\circ}, 25^{\circ}, 30^{\circ}, 35^{\circ}$ dan $40^{\circ}$ di ketiga model sudu turbin.

4. Melakukan analisis data hasil pengukuran RPM turbin sudu setengah lingkaran, sudu segitiga dan sudu sirip.

5. Menghitung luas segitiga kerja pada turbin sudu setengah lingkaran, sudu segitiga dan sudu sirip.

6. Menarik kesimpulan dari analasis yang telah dilakukan.

\section{HASIL DAN PEMBAHASAN}

\subsection{Pemodelan Pembangkit Listrik Tenaga Mikro Hidro}

Pemodelan pembangkit listrik tenaga mikro hidro (PLTMH) adalah suatu pembangkit listrik yang menggunakan tenaga air sebagai penggeraknya. Cara kerja sistem PLTMH ini diawali dengan pompa menghisap air yang terdapat pada bak, kemudian air dialirkan melalui pipa sampai ke sudu kincir hingga kincir berputar. Terjadi energi mekanik saat kincir berputar, kincir terhubung dengan pulley kincir melalui sebuah poros. Dengan sebuah belt, pulley kincir dihubungkan dengan pulley yang terhubung pada rotor generator (pulley generator). Putaran yang terjadi pada kincir akan memutar generator melalui kedua pulley yang terhubung. Generator akan merubah energi mekanik menjadi energi listrik. Pada pipa akan dipasang manometer untuk mengukur tekanan air. Untuk mengukur putaran kincir dan generator dipergunakan tachometer.

Data yang dicatat pada pemodelan pembangkit listrik tenaga mikro hidro (PLTMH) ini adalah putaran pada kincir dan putaran pada generator. Prototype PLTMH pada Gambar 8.

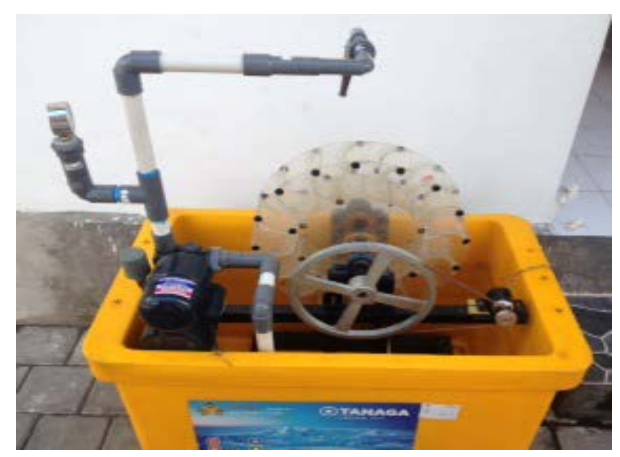

Gambar 8. Prototype PLTMH

\subsection{Posisi Nozzle dan Sudut Nozzle}

Posisi nozzle adalah posisi yang didapat dari sudut yang terbentuk antara lengan nozzle dan garis vertikal dari titik tengah kincir, dan sudut nozzle adalah sudut yang terbentuk antara lengan nozzle dengan nozzle. Posisi nozzle dan sudut nozzle sangat berpengaruh terhadap arah putaran roda kincir, tergantung dari penempatan nozzle tersebut. posisi nozzle dan sudut nozzle pada turbin PLTMH dapat dilihat pada Gambar 9 , 


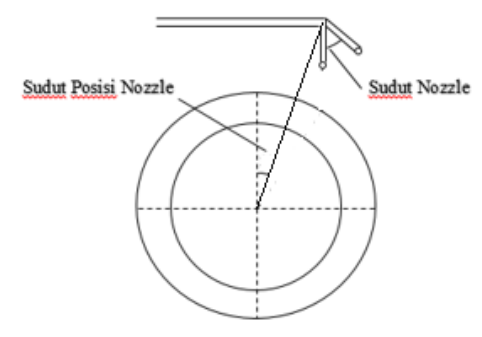

Gambar 9. Posisi Nozzle dan Sudut Nozzle

\subsubsection{Hasil Pengukuran Pengukuran Posisi Nozzle dan Sudut Nozzle Menggunakan Sudu Setengah Lingkaran}

Dari pengukuran yang telah dilakukan pada model sudu setengah lingkaran sesuai dengan parameter-parameter pengukuran pembangkit listrik tenaga mikro hidro, yaitu : sudut posisi nozzle dan sudut nozzle untuk mengetahui rpm turbin dan generator yang dihasilkan, dapat dilihat pada Tabel 1.

Tabel 1. Hasil Pengukuran Posisi Nozzle dan Sudut Nozzle Sudu Setengah Lingkaran

\begin{tabular}{|c|c|c|c|c|}
\hline No. & Posisi Nozzle & Sudut Nozzle & Putaran Kincir (rpm) & Putaran Generator (rpm) \\
\hline \multirow{7}{*}{1} & \multirow{7}{*}{$0^{0}$} & $0^{0}$ & 22 & 120 \\
\hline & & $5^{0}$ & 46 & 291 \\
\hline & & $10^{\circ}$ & 81 & 579 \\
\hline & & $15^{\circ}$ & 110 & 791 \\
\hline & & $20^{\circ}$ & 177 & 1261 \\
\hline & & $25^{\circ}$ & 216 & 1626 \\
\hline & & $30^{\circ}$ & 145 & 1016 \\
\hline \multirow{6}{*}{2} & \multirow{6}{*}{$15^{\circ}$} & $0^{0}$ & 42 & 297 \\
\hline & & $5^{0}$ & 86 & 636 \\
\hline & & $10^{\circ}$ & 124 & 946 \\
\hline & & $15^{\circ}$ & 174 & 1308 \\
\hline & & $20^{\circ}$ & 221 & 1711 \\
\hline & & $25^{\circ}$ & 45 & 325 \\
\hline \multirow{4}{*}{3} & \multirow{4}{*}{$30^{\circ}$} & $0^{0}$ & 110 & 822 \\
\hline & & $5^{0}$ & 146 & 870 \\
\hline & & $10^{\circ}$ & 173 & 1307 \\
\hline & & $15^{\circ}$ & 29 & 186 \\
\hline \multirow{3}{*}{4} & \multirow{3}{*}{$45^{\circ}$} & $0^{\circ}$ & 110 & 847 \\
\hline & & $5^{0}$ & 181 & 1371 \\
\hline & & $10^{0}$ & 199 & 1495 \\
\hline \multirow{2}{*}{5} & \multirow{2}{*}{$60^{\circ}$} & $0^{0}$ & 200 & 1520 \\
\hline & & $5^{0}$ & 194 & 1448 \\
\hline 6 & $75^{\circ}$ & $0^{0}$ & 67 & 552 \\
\hline
\end{tabular}

Hasil Pengukuran yang diperoleh pada Tabel 1 adalah rata-rata pengukuran dari lima kali pengulangan pada masingmasing parameter pemodelan pembangkit listrik tenaga mikro hidro yang diukur. Grafik rpm kincir dan generator, sudut posisi nozzle $0^{0}$ pada sudu setengah lingkaran dapat dilihat pada Grafik 1,

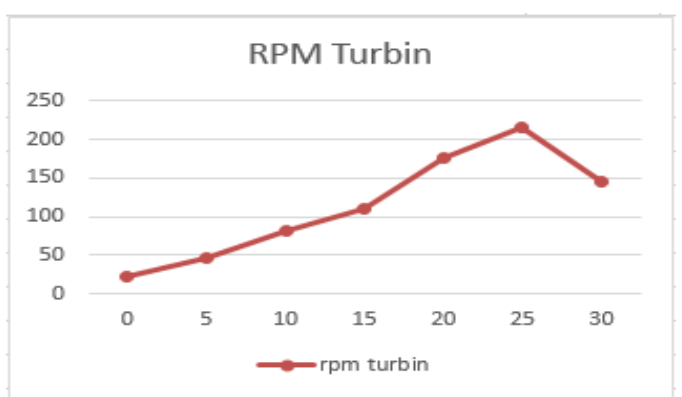

Grafik 1. RPM Turbin Sudut Posisi Nozzle $0^{0}$ Pada Sudu Setengah Lingkaran

\subsubsection{Hasil Pengukuran Pengukuran Posisi Nozzle dan Sudut Nozzle Menggunakan Sudu Segitiga \\ Dari pengukuran yang telah dilakukan} pada model sudu segitiga sesuai dengan parameter-parameter pengukuran pembangkit listrik tenaga mikro hidro, yaitu : sudut posisi nozzle dan sudut nozzle untuk mengetahui rpm turbin dan generator yang dihasilkan, dapat dilihat pada Tabel 2,

Tabel 2. Hasil Pengukuran Posisi Nozzle dan Sudut Nozzle Sudu Segitiga

\begin{tabular}{|c|c|c|c|c|}
\hline No. & Posisi Nozzle & Sudut Nozzle & Putaran Kincir (rpm) & Putaran Generator (rpm) \\
\hline \multirow{6}{*}{1} & \multirow{6}{*}{. } & $0^{\circ}$ & 29 & 199 \\
\hline & & $5^{\circ}$ & 44 & 305 \\
\hline & & $10^{\circ}$ & 77 & 589 \\
\hline & & $15^{\circ}$ & 125 & 922 \\
\hline & & $20^{\circ}$ & 178 & 1273 \\
\hline & & $25^{\circ}$ & 181 & 1294 \\
\hline \multirow{5}{*}{2} & \multirow{5}{*}{$15^{\circ}$} & $0^{\circ}$ & 48 & 317 \\
\hline & & $5^{\circ}$ & 97 & 722 \\
\hline & & $10^{\circ}$ & 146 & 1050 \\
\hline & & $15^{\circ}$ & 196 & 1410 \\
\hline & & $20^{\circ}$ & 144 & 1051 \\
\hline \multirow{3}{*}{3} & \multirow{3}{*}{$30^{\circ}$} & $0^{\circ}$ & 90 & 650 \\
\hline & & $5^{\circ}$ & 140 & 1069 \\
\hline & & $10^{\circ}$ & 201 & 1550 \\
\hline \multirow{3}{*}{4} & \multirow{3}{*}{$45^{\circ}$} & $0^{\circ}$ & 163 & 1177 \\
\hline & & $5^{\circ}$ & 198 & 1466 \\
\hline & & $10^{\circ}$ & 76 & 530 \\
\hline \multirow[b]{2}{*}{5} & \multirow[b]{2}{*}{$60^{\circ}$} & $0^{\circ}$ & 186 & 1382 \\
\hline & & $5^{\circ}$ & 158 & 1144 \\
\hline 6 & $75^{\circ}$ & $0^{\circ}$ & 144 & 834 \\
\hline
\end{tabular}

Hasil Pengukuran yang diperoleh pada Tabel 2 adalah rata-rata pengukuran dari lima kali pengulangan pada masingmasing parameter pemodelan pembangkit listrik tenaga mikro hidro yang diukur. Grafik rpm kincir dan generator, sudut posisi nozzle $0^{0}$ pada sudu segitiga dapat dilihat pada Grafik 2, 


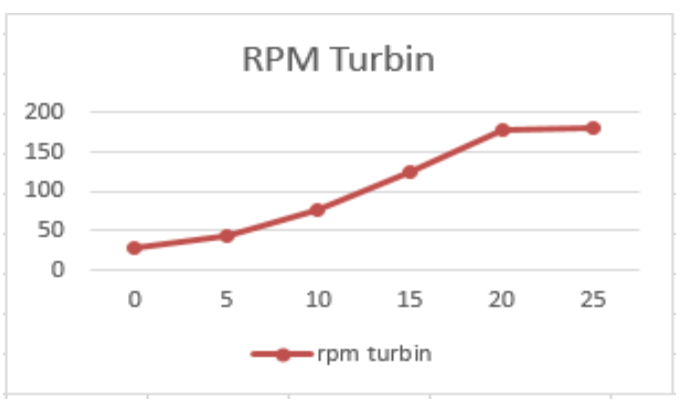

Grafik 2. RPM Turbin Sudut Posisi Nozzle $0^{0}$ Pada Sudu Segitiga

\subsubsection{Hasil Pengukuran Pengukuran Posisi Nozzle dan Sudut Nozzle Menggunakan Sudu Sirip}

Dari pengukuran yang telah dilakukan pada model sudu sirip sesuai dengan parameter-parameter pengukuran pembangkit listrik tenaga mikro hidro, yaitu : sudut posisi nozzle dan sudut nozzle untuk mengetahui rpm turbin dan generator yang dihasilkan, dapat dilihat pada Table 3.

Tabel 3. Hasil Pengukuran Posisi Nozzle dan Sudut Nozzle Sudu Sirip

\begin{tabular}{|c|c|c|c|c|}
\hline No. & Posisi Nozzle & Sudut Nozzle & Putaran Kincir (rpm) & Putaran Generator (rpm) \\
\hline \multirow{7}{*}{1} & \multirow{7}{*}{$0^{\circ}$} & $0^{\circ}$ & 20 & 134 \\
\hline & & $5^{\circ}$ & 29 & 185 \\
\hline & & $10^{\circ}$ & 38 & 271 \\
\hline & & $15^{\circ}$ & 114 & 816 \\
\hline & & $20^{\circ}$ & 186 & 1368 \\
\hline & & $25^{\circ}$ & 162 & 1163 \\
\hline & & $30^{\circ}$ & 111 & 793 \\
\hline \multirow{6}{*}{2} & \multirow{6}{*}{$15^{0}$} & $0^{\circ}$ & 33 & 221 \\
\hline & & $5^{\circ}$ & 90 & 696 \\
\hline & & $10^{\circ}$ & 146 & 1083 \\
\hline & & $15^{\circ}$ & 186 & 1368 \\
\hline & & $20^{\circ}$ & 155 & 1158 \\
\hline & & $25^{\circ}$ & 145 & 1071 \\
\hline \multirow{4}{*}{3} & \multirow{4}{*}{$30^{\circ}$} & $0^{\circ}$ & 156 & 1154 \\
\hline & & $5^{\circ}$ & 199 & 1495 \\
\hline & & $10^{\circ}$ & 185 & 1424 \\
\hline & & $15^{\circ}$ & 120 & 866 \\
\hline \multirow{3}{*}{4} & \multirow{3}{*}{$45^{\circ}$} & $0^{\circ}$ & 170 & 1229 \\
\hline & & $5^{\circ}$ & 200 & 1520 \\
\hline & & $10^{\circ}$ & 90 & 722 \\
\hline \multirow{2}{*}{5} & \multirow{2}{*}{$60^{\circ}$} & $0^{\circ}$ & 206 & 1604 \\
\hline & & $5^{\circ}$ & 130 & 976 \\
\hline 6 & $75^{\circ}$ & $0^{\circ}$ & 20 & 150 \\
\hline
\end{tabular}

Hasil Pengukuran yang diperoleh pada Tabel 3 adalah rata-rata pengukuran dari lima kali pengulangan pada masingmasing parameter pemodelan pembangkit listrik tenaga mikro hidro yang diukur. Grafik rpm kincir dan generator, sudut posisi nozzle $0^{0}$ pada sudu sirip dapat dilihat pada Grafik 3,

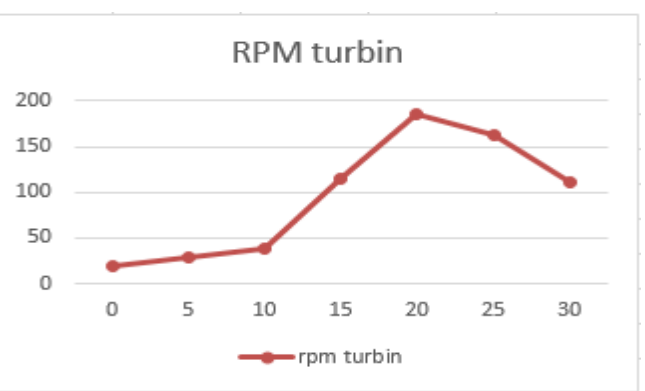

Grafik 3. RPM Turbin Sudut Posisi Nozzle $0^{0}$ Pada Sudu Sirip

\subsection{Analisis Luasan Segitiga Kerja}

Dari analisis luasan segitiga kerja yang telah dilakukan, dapat ditemukan salah satu bentuk luasan segitiga kerja yaitu sudut posisi nozzle $0^{0}$ dengan sudut nozzle pada $25^{\circ}$ yang menghasilkan rpm yang tertingi pada sudu setengah lingkaran seperti pada Gambar 10,

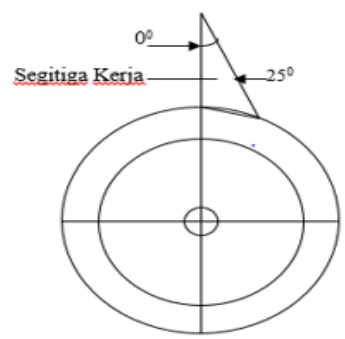

Gambar 10. Segitiga Kerja Sudut Posisi Nozzle $0^{\circ}$ dan Sudut Nozzle $25^{\circ}$ Pada Sudu Setengah Lingkaran

Dapat juga ditemukan bentuk luasan segitiga kerja pada posisi nozzle $15^{\circ}, 30^{\circ}$, $45^{\circ}, 60^{\circ}, 75^{\circ}$ yang menghasilkan rpm tertinggi pada sudu setengah lingkaran, sudu sirip dan

Luas segita kerja pada turbin sudu setengah lingkaran, sudu segitiga dan sudu sirip dapat dihitung setelah mengukur panjang sisi luasan segitiga kerja yang terdiri dari sisi $A B$, sisi $B C$, sisi $A C$ dan titik bantu D. segitiga kerja setelah gambar diputar seperti pada Gambar 11,

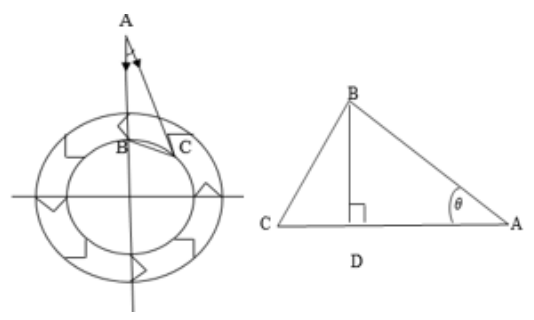


Gambar 11. Sisi Segitiga Kerja

Luas segitiga kerja dapat dihitung dengan menggunaan persamaan sebagai berikut :

$$
\sin \theta
$$

$$
D B
$$

Dimana sisi DB adalah tinggi dari segitiga kerja dan sisi AC adalah alasnya, maka luas segitiga kerja dihitung menggunakan rumus 1

$$
L=\frac{1}{2} \times A C \times D B
$$

\subsubsection{Hasil Perhitungan Luasan Segitiga Kerja Pada Turbin Sudu Setengah Lingkaran}

Hasil perhitungan luas segitiga kerja secara matematis, sesuai dengan Rumus 1 pada model sudu setengah lingkaran yang ditentukan oleh posisi nozzle dan sudut nozzle sehingga menghasilkan rpm yang tertinggi adalah pada Tabel 4 ,

Tabel 4. Hasil Perhitungan Luasan Segitiga Kerja Pada Sudu Setengah Lingkaran

\begin{tabular}{|c|c|c|c|c|c|c|c|}
\hline No. & $\begin{array}{c}\text { Posisi } \\
\text { Nozzle }\end{array}$ & $\begin{array}{c}\text { Sudut } \\
\text { Nozzle }\end{array}$ & $\begin{array}{c}\text { AC } \\
(\mathrm{cm})\end{array}$ & $\begin{array}{c}\text { BD } \\
(\mathbf{c m})\end{array}$ & $\begin{array}{c}\text { Luas Segitiga } \\
\text { Kerja }\left(\mathrm{cm}^{2}\right)\end{array}$ & $\begin{array}{c}\text { RPM } \\
\text { kincir }\end{array}$ & $\begin{array}{c}\text { RPM } \\
\text { Generator }\end{array}$ \\
\hline 1 & $0^{0}$ & $25^{0}$ & 52 & 13.86 & 360.36 & 216 & 1626 \\
\hline 2 & $15^{\circ}$ & $20^{0}$ & 46 & 11.49 & 264.27 & 221 & 1711 \\
\hline 3 & $30^{\circ}$ & $10^{0}$ & 43 & 6.25 & 134.37 & 173 & 1307 \\
\hline 4 & $45^{\circ}$ & $10^{0}$ & 46.5 & 6.63 & 154.14 & 199 & 1495 \\
\hline 5 & $60^{\circ}$ & $0^{0}$ & 0 & 0 & 0 & 200 & 1520 \\
\hline 6 & $75^{\circ}$ & $0^{0}$ & 0 & 0 & 0 & 67 & 552 \\
\hline
\end{tabular}

Dari data hasil perhitungan luas segitiga kerja pada model sudu setengah lingkaran yang telah didapat pada Tabel 4, maka dapat dibuat grafiknya untuk mengetahui hubungan antara luas segitiga kerja dan rpm tertinggi yang dihasilkan pada Grafik 4,

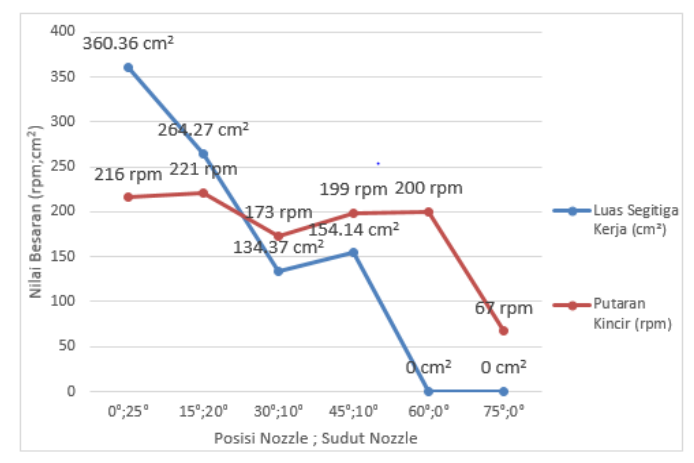

Grafik 4. Luas Segitiga Kerja dan RPM Tertinggi Pada Sudu Setengah Lingkaran

Pada grafik 4 dapat dilihat bahwa pada sudu turbin setengah lingkaran, luas segitiga kerja menghasilkan rpm yang semakin besar, seperti pada saat sudut posisi nozzle $0^{0}$ dan sudut nozzle $25^{\circ}$ dengan luasan segitiga kerja $360,36 \mathrm{~cm}^{2}$ menghasilkan $216 \mathrm{rpm}$ pada putaran kincir dan 1626 pada putaran generator, dan pada saat sudut posisi nozzle $15^{\circ}$ dan sudut nozzle $20^{\circ}$ dengan luasan segitiga kerja $264.27 \mathrm{~cm}^{2}$ menghasilkan $221 \mathrm{rpm}$ pada putaran kincir dan 1711 pada putaran generator, sedangkan pada saat sudut posisi nozzle $30^{\circ}$ dan sudut nozzle $10^{\circ}$ luas segitiga kerjanya $134.37 \mathrm{~cm}^{2}$ dan menghasilkan $173 \mathrm{rpm}$ pada putaran kincir dan $1307 \mathrm{rpm}$ pada putaran generator. Hal ini menunjukan luas segitiga kerja berpengaruh terhadap rpm yang dihasilkan.

\subsubsection{Hasil Perhitungan Luasan Segitiga Kerja Pada Turbin Sudu Segitiga}

Hasil perhitungan luas segitiga kerja secara matematis, sesuai dengan Rumus 1 pada model sudu segitiga yang ditentukan oleh posisi nozzle dan sudut nozzle sehingga menghasilkan rpm yang tertinggi dapat dilihat pada Tabel 5 ,

Tabel 5. Hasil Perhitungan Luasan Segitiga Kerja Pada Sudu Segitiga

\begin{tabular}{|c|c|c|c|c|c|c|c|}
\hline No. & $\begin{array}{c}\text { Posisi } \\
\text { Nozzle }\end{array}$ & $\begin{array}{c}\text { Sudut } \\
\text { Nozzle }\end{array}$ & $\begin{array}{c}\text { AC } \\
(\mathbf{c m})\end{array}$ & $\begin{array}{c}\text { BD } \\
(\mathbf{c m})\end{array}$ & $\begin{array}{c}\text { Luas Segitiga } \\
\text { Kerja }\left(\mathbf{c m}^{2}\right)\end{array}$ & $\begin{array}{c}\text { RPM } \\
\text { kincir }\end{array}$ & $\begin{array}{c}\text { RPM } \\
\text { Generator }\end{array}$ \\
\hline 1 & $0^{0}$ & $25^{0}$ & 45 & 14.28 & 321.3 & 181 & 1294 \\
\hline 2 & $15^{\circ}$ & $15^{0}$ & 41 & 8.62 & 176.81 & 196 & 1410 \\
\hline 3 & $30^{\circ}$ & $10^{0}$ & 43.5 & 6.20 & 134.95 & 201 & 1550 \\
\hline 4 & $45^{\circ}$ & $5^{0}$ & 42 & 3.39 & 71.25 & 198 & 1466 \\
\hline 5 & $60^{\circ}$ & $0^{0}$ & 0 & 0 & 0 & 186 & 1382 \\
\hline 6 & $75^{\circ}$ & $0^{0}$ & 0 & 0 & 0 & 144 & 834 \\
\hline
\end{tabular}

Dari data hasil perhitungan luas segitiga kerja pada model sudu segitiga yang telah didapat pada Tabel 5, maka dapat dibuat grafiknya untuk mengetahui hubungan antara luas segitiga kerja dan rpm tertinggi yang dihasilkan, dapat dilihat pada Grafik 5. 


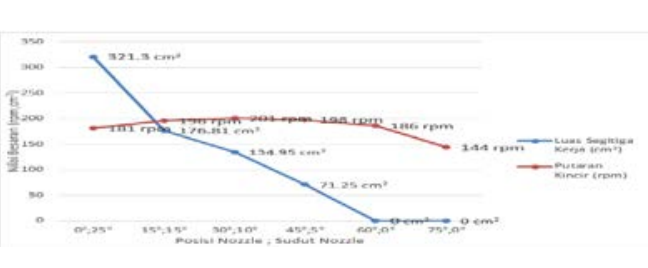

Grafik 5. Luas Segitiga Kerja dan RPM Tertinggi Pada Sudu Segitiga

Pada Grafik 5 dapat dilihat bahwa luas segitiga kerja pada model sudu segitiga tidak berpengaruh, entah luasnya besar ataupun kecil terhadap rpm yang dihasilkan. disetiap sudut posisi nozzle, rpm turbin yang dihasilkan relatif stabil, tidak dipengaruhi seberapapun besar luas segitiganya. sehingga dapat dikatakan bahwa luas segitiga kerja pada sudu segitiga tidak berpengaruh terhadap rpm yang dihasilkan.

\subsubsection{Hasil Perhitungan Luasan Segitiga Kerja Pada Turbin Sudu Sirip}

Hasil perhitungan luas segitiga kerja secara matematis, sesuai dengan rumus 1 pada model sudu sirip yang ditentukan oleh posisi nozzle dan sudut nozzle sehingga menghasilkan rpm yang tertinggi dapat dilihat pada Tabel 6,

Tabel 6. Hasil Perhitungan Luasan Segitiga Kerja Pada Sudu Sirip

\begin{tabular}{|c|c|c|c|c|c|c|c|}
\hline No. & $\begin{array}{c}\text { Posisi } \\
\text { Nozzle }\end{array}$ & $\begin{array}{c}\text { Sudut } \\
\text { Nozzle }\end{array}$ & $\begin{array}{c}\text { AC } \\
(\mathrm{cm})\end{array}$ & $\begin{array}{c}\text { BD } \\
(\mathrm{cm})\end{array}$ & $\begin{array}{c}\text { Luas Segitiga } \\
\left.\text { Kerja (cm }{ }^{2}\right)\end{array}$ & $\begin{array}{c}\text { RPM } \\
\text { kincir }\end{array}$ & $\begin{array}{c}\text { RPM } \\
\text { Generator }\end{array}$ \\
\hline 1 & $0^{0}$ & $20^{0}$ & 40 & 10.88 & 217.6 & 186 & 1368 \\
\hline 2 & $15^{0}$ & $15^{0}$ & 39 & 8.25 & 160.87 & 186 & 1368 \\
\hline 3 & $30^{0}$ & $5^{0}$ & 39 & 3.21 & 62.59 & 199 & 1495 \\
\hline 4 & $45^{\circ}$ & $5^{0}$ & 42 & 3.46 & 72.66 & 200 & 1520 \\
\hline 5 & $60^{0}$ & $0^{0}$ & 0 & 0 & 0 & 206 & 1604 \\
\hline 6 & $75^{\circ}$ & $0^{0}$ & 0 & 0 & 0 & 20 & 150 \\
\hline
\end{tabular}

Dari data hasil perhitungan luas segitiga kerja pada model sudu sirip yang telah didapat pada Tabel 6, maka dapat dibuat grafiknya untuk mengetahui hubungan antara luas segitiga kerja dan rpm tertinggi yang dihasilkan, dapat dilihat pada Grafik 6,

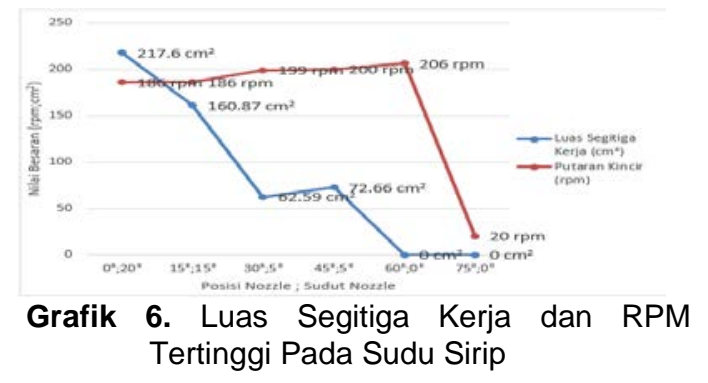

Pada Grafik 6 dapat dilihat bahwa luas segitiga kerja pada model sudu sirip tidak berpengaruh, entah luasnya besar ataupun kecil terhadap rpm yang dihasilkan. Terlihat pada grafik 6 disetiap sudut posisi nozzle, rpm turbin yang dihasilkan relatif stabil, tidak dipengaruhi seberapapun besar luas segitiganya. sehingga dapat dikatakan bahwa luas segitiga kerja pada sudu sirip tidak berpengaruh terhadap rpm yang dihasilkan.

\section{KESIMPULAN}

Simpulan yang dapat diambil berdasarkan hasil dari pengujian dan pembahasan yang telah dilakukan adalah sebagai berikut :

1. Pada sudu turbin setengah lingkaran, luas segitiga kerja menghasilkan rpm yang makin besar, seperti pada saat sudut posisi nozzle $0^{\circ}$ dan sudut nozzle $25^{\circ}$ dengan luasan segitiga kerja 360,36 $\mathrm{cm}^{2}$ menghasilkan $216 \mathrm{rpm}$ pada putaran kincir dan 1626 pada putaran generator, dan pada saat sudut posisi nozzle $15^{\circ}$ dan sudut nozzle $20^{\circ}$ dengan luasan segitiga kerja $264.27 \mathrm{~cm}^{2}$ menghasilkan $221 \mathrm{rpm}$ pada putaran kincir dan 1711 pada putaran generator, sedangkan pada saat sudut posisi nozzle $30^{\circ}$ dan sudut nozzle $10^{\circ}$ luas segitiga kerjanya 134.37 $\mathrm{cm}^{2}$ dan menghasilkan $173 \mathrm{rpm}$ pada putaran kincir dan $1307 \mathrm{rpm}$ pada putaran generator. Hal ini menunjukan luas segitiga kerja berpengaruh terhadap rpm yang dihasilkan.

2. Pada sudu turbin segitiga, luas segitiga kerja pada model sudu segitiga tidak berpengaruh, entah luasnya besar ataupun kecil terhadap rpm yang dihasilkan. Pada setiap sudut posisi nozzle, rpm turbin yang dihasilkan relatif stabil, tidak dipengaruhi seberapapun besar luas segitiganya. sehingga dapat dikatakan bahwa luas segitiga kerja pada sudu segitiga tidak berpengaruh terhadap rpm yang dihasilkan.

3. Pada sudu turbin sirip, luas segitiga kerja pada model sudu segitiga tidak berpengaruh, entah luasnya besar ataupun kecil terhadap rpm yang dihasilkan. Pada setiap sudut posisi nozzle, rpm turbin yang dihasilkan relatif stabil, tidak dipengaruhi seberapapun besar luas segitiganya. sehingga dapat dikatakan bahwa luas segitiga kerja pada sudu sirip tidak berpengaruh terhadap rpm yang dihasilkan. 


\section{DAFTAR PUSTAKA}

[1]. Kristiati, M. T.H., 2011. Sumber Energi Penghasil Listrik.Cetakan Pertama.Citra Aji Parama. Yogyakarta.

[2]. Dewa, N.K.P.N., 2009. Kajian Potensi Pengembangan Pembangkit Listrik Tenaga Mikrohidro Memanfaatkan Aliran Sungai Kelampuak di Desa Tamblang-Buleleng. Bali : Universitas Udayana.

[3]. Larasakti, dkk. "Pembuatan dan Pengujian Pembangkit Listrik Tenaga
Mikrohidro Turbin Banki Daya 200 Watt". Makasar: Universitas Hasanudin, 2012.

[4]. Jasa, L., 2015. Investigasi sudut Nozzle dan sudut kelengkungan sudu turbin air untuk peningkatan efisiensi mikro hidro. (Disertasi). Surabaya : ITS.

[5]. Weking, dkk, 2015. Modul Simulasi Kontrol Hidro Power Untuk Praktikum Mahasiswa Teknik Elektro Universitas Udayana. 